\title{
Time Management Skills. Academic Achievements and Life Satisfaction. A Case Study at Bucharest University of Economic Studies
}

\author{
Elena-Ramona RICHIȚEANU-NĂSTASE ${ }^{1}$ \\ Camelia ST ĂICULESCU ${ }^{2}$ \\ Maria Liana LĂCĂTUS ${ }^{3}$
}

\begin{abstract}
Time is one of the most valuable resources. A given period of time can be occupied with interesting or boring activities that generates different perceptions on it and affects individuals differently. As consequence, individuals have developed different time management skills. While some individuals demonstrate time management skills in a 'natural' manner, other have to develop these categories of skills. This paper is verifying the established correlations between time management skills and academic achievements, on one side, and life satisfaction, on the other side, in order to see and measure their relevance for young people by analysing time management skills demonstrated by students from Bucharest University of Economic Studies enrolled in bachelor programs. We are presenting the research we have conducted on 150 students from schools of economics, business and public administration, our findings and recommendations for effective development of time management skills to students.
\end{abstract}

Keywords: time management; time management skills; academic achievement; life satisfaction.

JEL classification: I23; I31; D23; D83; D91.

DOI: $10.24818 /$ RMCI.2018.2.102

\section{Introduction}

What is time management? Every day we use expressions such as "time flies", "time bound", "stressed by time", "flexible time", "planning, organizing and prioritizing your life" underlining the idea that time is one of the most valuable resources we have and it is our responsibility to use it properly. A given period of time can be occupied with interesting or boring activities that generates different

\footnotetext{
${ }^{1}$ Richiţeanu-Năstase Elena-Ramona ${ }^{1}$ Bucharest University of Economic Studies, E-mail: elena.richiteanu@dppd.ase.ro, Telephone: +40722299634

2 Stăiculescu Camelia, Bucharest University of Economic Studies, E-mail: cameliastaiculescu@dppd.ase.ro, Telephone: +40766364814

${ }^{3}$ Lăcătuş Maria Liana, Bucharest University of Economic Studies, E-mail: mlacatus2000@yahoo.com, Telephone: +40740017788
} 
perceptions on it and affects individuals differently. As consequence, individuals have developed different time management skills. While some individuals demonstrate time management skills in a 'natural' manner, other has to develop these categories of skills. By definition, time management skills means capacities to use the time in an effective way and is related with the capacity to establish achievable objectives, to identify priorities, to monitor the progress, and to be organized (Classes at al., 2007). The proper, efficiently use of time can lead to positive individual result. (Britton\&Tesser, 1991).

Many researches have focused on this topic. For example, Mackenzie (1990) demonstrated a correlation between time management and quality of life elements, such as - a more balanced life, an increased productivity or in achieving objectives. Crutsinger (1994) concluded that time management requires the determination of a course of action through setting of objectives, deciding which is the most important and prioritization of other activities, estimating correctly the time, adapting to the unknown situations (problem solving), frequently reconsider objectives and priorities and observing typical behaviour.

Time management was described through many terms such as: spontaneity, balance, flexibility and control of time (Lakein, 1973), prioritization and respecting those priorities (Soucie, 1986), prioritization and planning activities (Jordan et al., 1989), the process in which an individual achieves tasks and objectives (Schuler, 1979), the process in which an individual obtains control over time and his actions (Oncken \& Wass, 1985). Whatever the definition given we see that the focus was on identifying some components of time management. Macon, Shahani, Dipbaye\& Phillips (1990) identified 4 components: setting objectives, mechanics, preferences for organization, perception of controlling the time. Britton și Tesser (1991) identified 3 factors: short term planning, long term planning and attitudes. In 1995, Mark Trueman and James Hartley reduced time management components at two: daily planning and confidence in long term planning. This approach will be used in our research. The two authors mentioned above have a solid analysis of data using the initial Britton\& Tesser's questionnaire for time management but the threecomponent was not sustained and a revised two-component scale measuring "daily planning" and "confidence in long term planning" was preferred.

The importance in studying time management level and abilities lays in the possibility of finding different correlation with impact on training and education. The main idea is that if time management is so important then it has to be developed to increase academic achievements, job performance and overall satisfaction with life. An analysis of the research in this area show many different interesting results. Some studies are focused on the correlation between time management and academic achievements (Britton, Bruce K.; Tesser, Abraham; Misra\&McKean, 2000; Campbell \& Svenson, 1992). Macan et al. (1990) revealed a correlation between organizational skills and age for women over 20. Some studies have been focused on time management and job performance (Barling et al., 1996), (Britton \& Tesser, 1991; Macan et al., 1990). An interesting research finds a correlation between time management and satisfaction with life (Dalli, 2014). 


\section{Methodology}

Taking in consideration these findings we conducted an integrative research to verify these data in our university and to propose effective ways of developing time management skills of students. The initial instrument used was Britton and Tesser's time management questionnaire, but we considered that the 17 item revised scale proposed by Mark Trueman and James Hartley show more consistency of the data and the validity of the instrument.

\subsection{Objectives}

Our research aims the following: firstly, to identify time management abilities, satisfaction with life and academic performance of the students from Bucharest University of Economic Studies and secondly, to identify particularities of correlations between time management abilities and academic performance of the students, between time management abilities and satisfaction with life, between short range planning and female respondents in the case of Bucharest University of Economic Studies students.

\subsection{Participants}

Our sample consisted of 150 students (54 men and 96 women) from Bucharest University of Economic Studies, Romania enrolled in bachelor programs: economics, business and public administration. Most of the respondents were 22 years old $\left(3^{\text {rd }}\right.$ year of study, $\left.60 \%\right)$.

\subsection{Instrument}

We used 2 different instruments to obtain the data required for our study.

Firstly, we used the Trueman`s and Hartley`s 17 revised scale of time management questionnaire. Each scale item had five response categories: 'Always', 'Frequently', 'Sometimes', 'Infrequently' and 'Never'. These were scored from 1 to 5, five indicating a positive attempt at managing time. For items 8, 10,12 and 15 the scores were reversed. The response, 'Always' was scored as 1 and 5 for 'Never'. A student could score a minimum of 17 and a maximum of 85 on the 17-item Time Management Scale; a minimum of 7 and a maximum of 35 on the Short Range Planning sub-scale; a minimum 6 a minimum 30 on the Time Attitudes sub-scale; and a minimum 4 and a maximum of 20 on the Long Range Planning sub-scale.

The internal reliability of the 17-item scale was assessed by the authors using Cronbach's alpha. The total scale was shown to have a reasonable level of internal reliability (Alpha=.77). The values of Alpha for the Short Range Planning, Time Attitudes, and Long Range Planning sub-scales were .81, .57 and .48 respectively. Although the long range planning wasn't found reliable it was used just to be assessed in this study. We consider the revised 17 scale of time 
management a better and suited instrument of time management abilities that can be used in different cultural background.

The second instrument used was the Satisfaction with life scale proposed by Ed Diener in 1985 . We used the 2006 form of the instrument. The instrument has 5 items with a 7 Likert scale. The scores range from 5 to 35 . The $30-35$ score is a very high score and means a highly satisfied individual, 25-29 is a high score and means a satisfied individual, $20-24$ is an average score, $15-19$ is a slightly below average in life satisfaction, $10-14$ dissatisfied and 5-9 Extremely Dissatisfied. The Satisfaction With Life Scale (SWLS) was developed to assess satisfaction with the respondent's life as a whole.

For our present research we used along identification elements - gender, age, year of study, the average obtain in the previously semester as a way of identifying academic achievement levels and the employment status.

\subsection{Procedure}

To obtain the necessary data to our research we have made the following procedures:

- Integrating the instruments in only one instrument using Google forms application;

- Distribution, collecting and primary analysis of the obtained data (SPSS);

- Interpretation and discussion of the data.

\section{Data analysis and interpretation}

The data obtained reveal some interesting information. At a first glimpse (Table 1) there can be found some differences between the female and male students in terms of short range planning or time attitudes. The female students tend to be more satisfied with their life and have more positive time attitudes than boys. Male students tend to be more focused on short range planning, but the overall time management skills and long range planning of female and male students don't vary too much. What is evident here is that the level of satisfaction with life differs a lot between female and male students (apparently male students are more dissatisfied).

Table 1: Descriptive statistics

\begin{tabular}{|l|r|r|r|}
\hline \multicolumn{1}{|c|}{ Variable } & \multicolumn{1}{c|}{ N } & \multicolumn{1}{c|}{ Mean } & Std. Deviation \\
\hline Time management total & 150 & 61,13 & 7,220 \\
\hline Satisfaction with life total & 150 & 22,80 & 4,843 \\
\hline Short range planning & 150 & 11,87 & 1,807 \\
\hline Time attitudes & 150 & 20,73 & 2,520 \\
\hline
\end{tabular}

105 Review of International Comparative Management Volume 19, Issue 2, May 2018 


\begin{tabular}{|l|l|r|r|r|}
\hline \multicolumn{2}{|c|}{ Variable } & \multicolumn{1}{c|}{ N } & Mean & Std. Deviation \\
\hline \multirow{2}{*}{ Long range planning } & 150 & 27,53 & 5,668 \\
\hline \multirow{3}{*}{$\begin{array}{l}\text { Female } \\
\text { students }\end{array}$} & Time management total & 90 & 61,22 & 7,678 \\
\cline { 2 - 5 } & Satisfaction with life & 90 & 5,44 &, 882 \\
\cline { 2 - 5 } & Short range planning & 90 & 22,22 & 5,761 \\
\cline { 2 - 5 } & Time attitudes & 90 & 21,11 & 2,619 \\
\cline { 2 - 5 } & Long range planning & 90 & 11,89 & 2,147 \\
\cline { 2 - 5 } & Work status & 90 & 2,00 &, 866 \\
\hline \multirow{4}{*}{ stude } & Time management total & 60 & 61,00 & 7,183 \\
\cline { 2 - 6 } & Satisfaction with life & 60 & 4,67 & 1,033 \\
\cline { 2 - 6 } & Short range planning & 60 & 23,67 & 3,327 \\
\cline { 2 - 6 } & Time attitudes & 60 & 20,17 & 2,483 \\
\cline { 2 - 6 } & Long range planning & 60 & 11,83 & 1,329 \\
\cline { 2 - 6 } & Work status & & 2,67 &, 816 \\
\hline
\end{tabular}

After primary data analysis of correlation between management abilities and academic performance of the students, between time management abilities and satisfaction with life, between short range planning and female respondents we have found the following (Table 2. Correlations):

Table 2: Correlations

\begin{tabular}{|c|c|c|c|c|c|c|c|c|}
\hline & \multirow{2}{*}{\begin{tabular}{|c|}
$\begin{array}{c}\text { Time } \\
\text { management } \\
\text { total }\end{array}$ \\
1
\end{tabular}} & \multirow{2}{*}{\begin{tabular}{|r|}
$\begin{array}{c}\text { Satisfaction } \\
\text { with life }\end{array}$ \\
, 353 \\
\end{tabular}} & \multirow{2}{*}{\begin{tabular}{|r}
$\begin{array}{c}\text { Short } \\
\text { range } \\
\text { planning }\end{array}$ \\
, $869^{* *}$
\end{tabular}} & \multirow{2}{*}{$\begin{array}{r}\begin{array}{c}\text { Time } \\
\text { attitudes }\end{array} \\
, 825^{* *}\end{array}$} & \multirow{2}{*}{\begin{tabular}{|r|}
$\begin{array}{c}\text { Long } \\
\text { range } \\
\text { planning }\end{array}$ \\
, 350
\end{tabular}} & \multirow{2}{*}{\begin{tabular}{|r|}
$\begin{array}{l}\text { Work } \\
\text { status }\end{array}$ \\
,- 019
\end{tabular}} \\
\hline $\mathrm{F}$ & $\begin{array}{l}\text { Time } \\
\text { management }\end{array}$ & \begin{tabular}{|l|} 
Pearson \\
Correlation
\end{tabular} & & & & & & \\
\hline & & $\mathrm{N}$ & 90 & 90 & 90 & 90 & 90 & 90 \\
\hline & \multirow[t]{2}{*}{$\begin{array}{l}\text { Satisfaction } \\
\text { with life }\end{array}$} & $\begin{array}{l}\text { Pear } \\
\text { Corr }\end{array}$ & ,353 & 1 & , 101 & , 084 & ,623 &,- 491 \\
\hline & & $\mathrm{N}$ & 90 & 90 & 90 & 90 & 90 & 90 \\
\hline & \multirow[t]{2}{*}{$\begin{array}{l}\text { Time } \\
\text { attitudes }\end{array}$} & $\begin{array}{l}\text { Pear } \\
\text { Corr }\end{array}$ &, $825^{* *}$ & ,084 & ,578 & 1 & ,358 & ,055 \\
\hline & & $\mathrm{N}$ & 90 & 90 & 90 & 90 & 90 & 90 \\
\hline \multirow[t]{5}{*}{$\bar{M}$} & $\begin{array}{l}\text { Time } \\
\text { management }\end{array}$ & $\begin{array}{l}\text { Pears } \\
\text { Corr }\end{array}$ & 1 & , 162 & ,962** & ,931** & ,880* & ,341 \\
\hline & total & $\mathrm{N}$ & 60 & 60 & 60 & 60 & 60 & 60 \\
\hline & \multirow[t]{2}{*}{$\begin{array}{l}\text { Satisfaction } \\
\text { with life }\end{array}$} & $\begin{array}{l}\text { Pearson } \\
\text { Correlation }\end{array}$ &, 162 & 1 & ,078 &,- 130 & ,243 &,- 158 \\
\hline & & $\mathrm{N}$ & 60 & 60 & 60 & 60 & 60 & 60 \\
\hline & Short range & Pearson & $962^{* *}$ & ,078 & 1 & ,904* &, 754 &, 540 \\
\hline
\end{tabular}




\begin{tabular}{|c|c|c|c|c|c|c|c|}
\hline \multicolumn{2}{|c|}{ Gender } & \multirow{2}{*}{\begin{tabular}{|c|} 
Time \\
management \\
total
\end{tabular}} & \multirow{2}{*}{$\begin{array}{c}\text { Satisfaction } \\
\text { with life }\end{array}$} & \multirow{2}{*}{\begin{tabular}{|c|} 
Short \\
range \\
planning \\
\end{tabular}} & \multirow{2}{*}{$\begin{array}{c}\text { Time } \\
\text { attitudes }\end{array}$} & \multirow{2}{*}{\begin{tabular}{|c|} 
Long \\
range \\
planning \\
\end{tabular}} & \multirow[t]{2}{*}{$\begin{array}{l}\text { Work } \\
\text { status }\end{array}$} \\
\hline \multirow[t]{3}{*}{ planning } & Correlation & & & & & & \\
\hline & \begin{tabular}{|l} 
Sig. (2- \\
tailed)
\end{tabular} & ,002 & ,884 & & ,013 & ,083 & ,269 \\
\hline & $\mathrm{N}$ & 60 & 60 & 60 & 60 & 60 & 60 \\
\hline \multirow[t]{3}{*}{$\begin{array}{l}\text { Time } \\
\text { attitudes }\end{array}$} & $\begin{array}{l}\text { Pearson } \\
\text { Correlation }\end{array}$ &, $931^{* * *}$ &,- 130 & ,904* & 1 & ,737 & ,427 \\
\hline & $\begin{array}{l}\text { Sig. (2- } \\
\text { tailed) } \\
\end{array}$ & ,007 & ,806 & ,013 & & ,095 & ,398 \\
\hline & $\mathrm{N}$ & 60 & 60 & 60 & 60 & 60 & 60 \\
\hline \multirow[t]{3}{*}{$\begin{array}{l}\text { Long range } \\
\text { planning }\end{array}$} & \begin{tabular}{|l|} 
Pearson \\
Correlation
\end{tabular} & ,880* & ,243 & ,754 & ,737 & 1 &,- 061 \\
\hline & \begin{tabular}{|l} 
Sig. (2- \\
tailed) \\
\end{tabular} & ,021 &, 643 & ,083 & ,095 & & ,908 \\
\hline & $\mathrm{N}$ & 60 & 60 & 60 & 60 & 60 & 60 \\
\hline
\end{tabular}

Firstly, the only clear correlation that we found was between female students, time management skills and their work status. Apparently, female working students (full time) have a worse time management skill level, than those unemployed. So a working female student doesn't get along with a job and daily courses at university. Secondly, we have found out some slightly correlation between satisfaction with life and time attitudes for the female students. This data indicate that if the things are getting done on time, day by day, piece by piece, without procrastination then they lead to a higher level of satisfaction with life. Thirdly, we have found out some slightly correlation between time attitudes and the work status. That means for female students that as they get a part time job and then a full time job they realize the importance of their time attitudes for getting things done. Fourthly, the satisfaction with life for male students find its source in the short range planning. The long range planning becomes important as the male students get a job.

Unfortunately we couldn't get relevant data to indicate a correlation of time management skills and academic performance (because the respondents had an average of 9 points) so we decided not to study this furtherer. We think that the data gathered are very important not only for the confirmation of previous data but also for the decision that can be taken by the university to help these students. 4

\section{Conclusions}

The data gathered in this study will be further analyzed. The initial study was only for bachelor students of Bucharest University of Economic Studies but other students had shown interest so we are extending our research to include master and doctoral degree students. 
In terms of research, we recommend expanding the present research on different age categories and education. It will be interesting to see if these gender differences are maintained. Also we have to wonder if these gender differences are a product of the socio-cultural and educational background of an individual and if so maybe we have to develop new educational practices to raise our children.

Starting from these findings, we think that is important for the university to organize preventive actions such as courses, workshops and lectures to develop time management skills in terms of short range planning and positive time attitudes.

We believe that these abilities can and should be developed through counselling focused on life objectives and attitudes, self-acceptance and personal satisfaction that derives from self-esteem.

The question remains open: are time management skills a predictor of life satisfaction, and if so how they take part of those essential life skills that lead to success?

\section{References}

1. Britton, Bruce K.; Tesser, Abraham, 1991. Effects of time-management practices on college grades. In Journal of Educational Psychology, Vol 83(3), 405-410., [Online], Available at: http://dx.doi.org/10.1037/0022-0663.83.3.405

2. Dalli, Mehmet, 2014. The university students' time management skills in terms of their academic life satisfaction and academic achievement levels. In Educational Research and reviews. Vol. 9(20), pp.1090-1096

3. Diener, E., Emmons, R. A., Larsen, R. J., \& Griffin, S., 1985. The Satisfaction with Life Scale. Journal of Personality Assessment, 49, 71-75.

4. Neill, J. T., 2016. The University Student Satisfaction and Time Management Questionnaire, [Online], Available at: https://en.wikiversity.org/wiki/Survey_ research_and_design_in_psychology/Assessment/Survey/TUSSTMQ9

5. Richiţeanu-Năstase, Elena-Ramona \& Stăiculescu, Camelia, 2015. The Impact of Career Factors on Students Professional Insertion. What Measures to be Taken by the University? Procedia - Social and Behavioral Sciences. 180. 1102-1108. [Online], Available at: https://doi.org/10.1016/j.sbspro. 2015.02.216

6. Stoilov, Todor, 2012. Time Management, - Croația: InTech, [Online], Available at: idl.isead.edu.es:8080/jspui/bitstream/10954/1767 /1/9789535103356.pdf

7. Trueman, Mark; Hartley, James, 1995. Mesuring time-management sckills: cross-cultural observation on Britton and Tesser's time management scale. ERIC, [Online], Available at: http://files.eric.ed.gov/fulltext/ED417667.pdf 